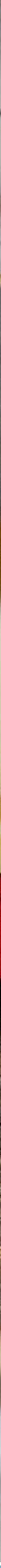

Ontwikkeling van een concept voor de bepaling van de gezondheidsstatus van vleeskuikens (onderdeel 1)

R.A. van Emous, j. van Riel, T. Veldkamp, P. van Wikselaar, J. van der Meulen en A.J.M. Jansman $\quad$ RAPPORT 1137

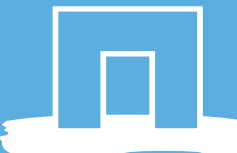





\section{Ontwikkeling van een concept voor de bepaling van de gezondheidsstatus van vleeskuikens (onderdeel 1)}
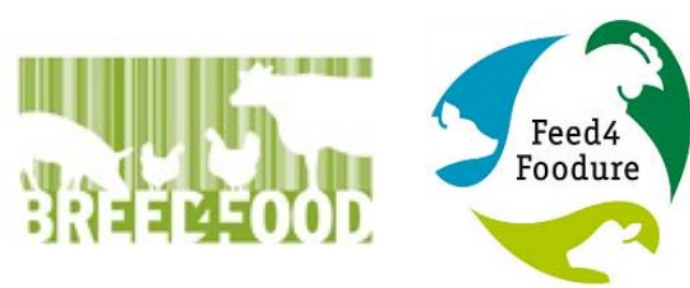

Dit onderzoek is uitgevoerd door Wageningen Livestock Research, in het kader van de PPS 'Breed\&Feed4Food' (AF-14215), medegefinancierd door het Ministerie van LNV (BO-47-001-008) en door de Vereniging Diervoederonderzoek Nederland (VDN). 
Van Emous, R.A., J. van Riel, A.J.M. Jansman, T. Veldkamp, P. van Wikselaar, J. van der Meulen, 2018. Ontwikkeling van een concept voor de bepaling van de gezondheidsstatus van vleeskuikens (onderdeel 1). Wageningen Livestock Research, Rapport 1137

In dit rapport worden de resultaten gepresenteerd van de ontwikkeling van een concept voor de bepaling van de gezondheidsstatus van vleeskuikens op bedrijfsniveau. Het doel van het onderzoek was om na te gaan in welke mate de variatie in technische resultaten van koppels dieren wordt beïnvloed door effecten op bedrijfsniveau of de variatie is toe te schrijven aan andere effecten, niet gerelateerd aan effecten op bedrijfsniveau (koppelniveau). Dit onderzoek is uitgevoerd door Wageningen Livestock Research, in het kader van de PPS 'Breed\&Feed4Food' (AF-14215), medegefinancierd door het Ministerie van LNV (BO-47-001-008) en door de Vereniging Diervoederonderzoek Nederland (VDN). Uit het onderzoek blijkt dat er een belangrijk bedrijfseffect is op de technische resultaten van vleeskuikens. Dit betekent dat er voldoende aanleiding is om voor een concept voor categorisering van de gezondheidsstatus van vleeskuikens uit te gaan van een indeling op bedrijfsniveau.

Dit rapport is gratis te downloaden op https://doi.org/10.18174/465631 of op www.wur.nl/livestock-research (onder Wageningen Livestock Research publicaties).

(C) 2018 Wageningen Livestock Research

Postbus 338, 6700 AH Wageningen, T 03174839 53, E info.livestockresearch@wur.nl, www.wur.nl/livestock-research. Wageningen Livestock Research is onderdeel van Wageningen University \& Research.

Wageningen Livestock Research aanvaardt geen aansprakelijkheid voor eventuele schade voortvloeiend uit het gebruik van de resultaten van dit onderzoek of de toepassing van de adviezen.

Alle rechten voorbehouden. Niets uit deze uitgave mag worden vermenigvuldigd en/of openbaar gemaakt worden door middel van druk, fotokopie, microfilm of op welke wijze dan ook zonder voorafgaande toestemming van de uitgever of auteur.

Wageningen Livestock Research is NEN-EN-ISO 9001:2015 gecertificeerd. Op al onze onderzoeksopdrachten zijn de Algemene Voorwaarden van de Animal Sciences Group van toepassing. Deze zijn gedeponeerd bij de Arrondissementsrechtbank Zwolle. 


\section{Inhoud}

Woord vooraf $\quad 5$

$\begin{array}{ll}\text { Samenvatting } & 7\end{array}$

1

$\begin{array}{lr}\text { Inleiding } & 9\end{array}$

2

$\begin{array}{ll}\text { Materiaal en methoden } & 11\end{array}$

3

$\begin{array}{ll}\text { Resultaten en discussie } & 12\end{array}$

3.1 Beschrijving van de data 12

3.1.1 Frequentie van algemene gegevens en kengetallen $\quad 12$

3.1.2 Gemiddelde en spreiding kengetallen 12

$\begin{array}{ll}3.1 .3 \text { Seizoen effect } & 13\end{array}$

$\begin{array}{lll}3.2 & \text { Statistische analyse } & 14\end{array}$

4

$\begin{array}{ll}\text { Conclusie } & 17\end{array}$

Literatuur

18 



\section{Woord vooraf}

Dit onderzoek is uitgevoerd door Wageningen Livestock Research, in het kader van de PPS 'Breed\&Feed4Food' (AF-14215), medegefinancierd door het Ministerie van LNV (BO-47-001-008) en door de Vereniging Diervoederonderzoek Nederland (VDN).

Het overall project heeft als doel om stikstofverliezen bij pluimvee te verminderen door kennis te ontwikkelen om voeders voor vleeskuikens ten aanzien van hun aminozuursamenstelling af te stemmen op de gezondheidsstatus van de dieren op bedrijven in de praktijk.

Het onderzoek in het huidige rapport richt zich is het ontwikkelen van een methodiek om de gezondheidsstatus van vleeskuikens op bedrijfsniveau op basis van beschikbare parameters van koppels op bedrijven in categorieën (suboptimaal, conventioneel en hoog) in te delen. Dit is een onderdeel van een project met als uiteindelijke doel om de voeding van vleeskuikens op bedrijfsniveau aan te passen aan de gezondheidsstatus van dieren op bedrijven waardoor efficiëntie van nutriënt gebruik wordt verbeterd.

De auteurs bedanken het VDN cluster Pluimvee voor de prettige samenwerking in het project.

Dr. A.J.M. (Alfons) Jansman

Projectleider 


\section{Samenvatting}

In de praktijk worden op vleeskuikenbedrijven grote verschillen in productieresultaten waargenomen. Uit wetenschappelijke literatuur blijkt dat de aminozuurbehoefte van vleeskuikens, naast diverse andere dier- en omgeving gerelateerde factoren, wordt beïnvloed door de gezondheidsstatus van het primaire vleeskuikenbedrijf. Bij een lage of suboptimale gezondheidsstatus van dieren wordt het immuunsysteem geactiveerd, hetgeen leidt tot een verhoogde behoefte van dit systeem voor essentiële nutriënten, waaronder aminozuren. Voorgaande gaat ten koste van nutriënten die beschikbaar zijn voor aanzet van lichaamsweefsels (groei).

$\mathrm{Er}$ is thans geen duidelijke eenduidige methodiek om de gezondheidsstatus van vleeskuikenbedrijven vast te stellen. Voor vleesvarkens is recent een methodiek ontwikkeld waarbij via de zogenaamde 'spinnenweb methode' de gezondheidsstatus van individuele vleesvarken bedrijven zichtbaar gemaakt kan worden. Door verschillende kenmerken op bedrijfsniveau, direct of indirect gerelateerd aan diergezondheid, in het spinnenweb te plaatsen kan uitgelezen worden in welke categorie (suboptimale, conventionele of hoge gezondheidsstatus) een bepaald bedrijf valt. De basis van het beschreven concept voor vleesvarkensbedrijven zou ook kunnen worden gebruikt voor het ontwikkelen van een vergelijkbaar concept voor vleeskuikenbedrijven. Een beperking in de vleeskuikensector is dat tijdens het slachtproces routinematig slechts het percentage afkeuringen en voetzoollaesie score per koppel worden gemonitord. Deze beide kenmerken verschaffen slechts indirect informatie over de gezondheidsstatus van vleeskuikenbedrijven. De kenmerken worden namelijk mede beïnvloed door diverse omgevingsfactoren (bv. klimaat, voeding, etc.)

Het doel van het onderhavige onderzoek was om meer inzicht te krijgen in welke gegevens in de praktijk bij vleeskuikenbedrijven gemonitord worden met als doel te onderzoeken welke gegevens het meest relevant zijn om te gebruiken voor een methodiek voor de bepaling van de gezondheidsstatus van vleeskuikenbedrijven. Het uiteindelijk doel van dit onderzoek was om na te gaan of er aanleiding is om voor de afstemming van de nutriëntsamenstelling van het voer op de gezondheidsstatus van vleeskuikens uit te gaan van een benadering op bedrijfsniveau in plaats van op koppelniveau.

Om meer inzicht te genereren omtrent de beschikbare gegevens voor de ontwikkeling van het gezondheidsconcept hebben een drietal mengvoederbedrijven geanonimiseerde koppelgegevens van bedrijven over de jaren medio 2013 - medio 2016 verstrekt. Na samenvoeging van de drie databases bevatte deze gegevens van in totaal 1.730 koppels. Na controle op volledigheid en geschiktheid van data bleven er gegevens van 80 vleeskuikenbedrijven over met in totaal 1.054 koppels (gemiddeld 13 koppels per bedrijf).

Uit de analyse van gegevens wordt geconcludeerd dat:

- Voor de kenmerken uitval, groei per dag, de gecorrigeerde voederconversie $\left(\mathrm{VC}_{1500}\right)$, en voetzoollaesie score er een significante invloed bestaat van de factor bedrijf.

- Het bedrijfseffect op de kenmerken groei/dag en $V_{1500}$ groter is dan op de kenmerken uitval en voetzoollaesie score.

- De variatie in gezondheidsstatus tussen vleeskuikenbedrijven, ten opzichte van de variatie tussen individuele koppels binnen bedrijven, voldoende groot is om in de toekomst de voersamenstelling op bedrijfsniveau af te stemmen op de gezondheidsstatus van vleeskuikens. 


\section{$1 \quad$ Inleiding}

In de praktijk worden op vleeskuikenbedrijven grote verschillen in productieresultaten waargenomen (Peter van Horne, WEcR, 2017, persoonlijke mededeling). Uit wetenschappelijke literatuur blijkt dat de aminozuurbehoefte van vleeskuikens, naast diverse andere dier- en omgeving gerelateerde factoren, wordt beïnvloed door de gezondheidsstatus (Klasing, 1998; Korver and Klasing, 2001; Klasing, 2007). $\mathrm{Bij}$ een lage of suboptimale gezondheidsstatus van dieren worden de verschillende onderdelen van het immuunsysteem geactiveerd, hetgeen leidt tot een verhoogde behoefte van dit systeem voor essentiële nutriënten, waaronder aminozuren. De sterkere vraag naar nutriënten leidt tot een verminderde beschikbaarheid van nutriënten voor aanzet van eiwit in het lichaam en beïnvloedt op die manier dus de productieresultaten. Voor het bepalen van de gezondheidsstatus van vleeskuikenbedrijven in het project ligt de nadruk op de gezondheid status gerelateerd aan klinische en subklinische aandoeningen welke invloed hebben op de zoötechnische prestaties van de kuikens. Naast klinische aandoeningen spelen subklinische, chronische bedrijfsgebonden aandoeningen hierbij een belangrijke rol.

$\mathrm{Er}$ is thans geen duidelijke eenduidige methodiek om de gezondheidsstatus van vleeskuikenbedrijven vast te stellen. In een literatuurstudie voor varkens werden de volgende kenmerken genoemd in relatie tot parameters die in verband staan met bedrijfsgezondheidsstatus: 1) productieresultaten; 2) aanwezigheid van specifieke pathogenen; 3) responsen en status van het immuunsysteem (Van der Peet Schwering en Jansman, 2007). In een vervolg hierop is door Kampman-van de Hoek (2015) in het kader van het project "Bedrijfsspecifieke Voeding voor Varkens" een zogenaamd spinnenweb concept ontwikkeld waarbij varkensbedrijven geclassificeerd worden op hun gezondheidsstatus op de volgende parameters: gecorrigeerde groei (g/dier/d), gecorrigeerde EW-conversie (EW/kg groei), uitval (\%), leverafwijkingen (\% afgekeurd), longafwijkingen ( $\%$ afgekeurd) en pleuritis (\%). Uit een indeling op deze hoofdpunten, met een bijbehorende puntenscore voor elk onderdeel, werd een "spinnenweb" weergave gebruikt dat kan fungeren als hulpmiddel voor het bepalen van de gezondheidsstatus van een bedrijf (figuur 1). Door de verschillende kenmerken in het spinnenweb te plaatsen kan uitgelezen worden in welke categorie een bepaald bedrijf valt. Binnen dit project werden de bedrijven onderverdeeld in bedrijven met een suboptimale, conventionele of hoge gezondheidsstatus.

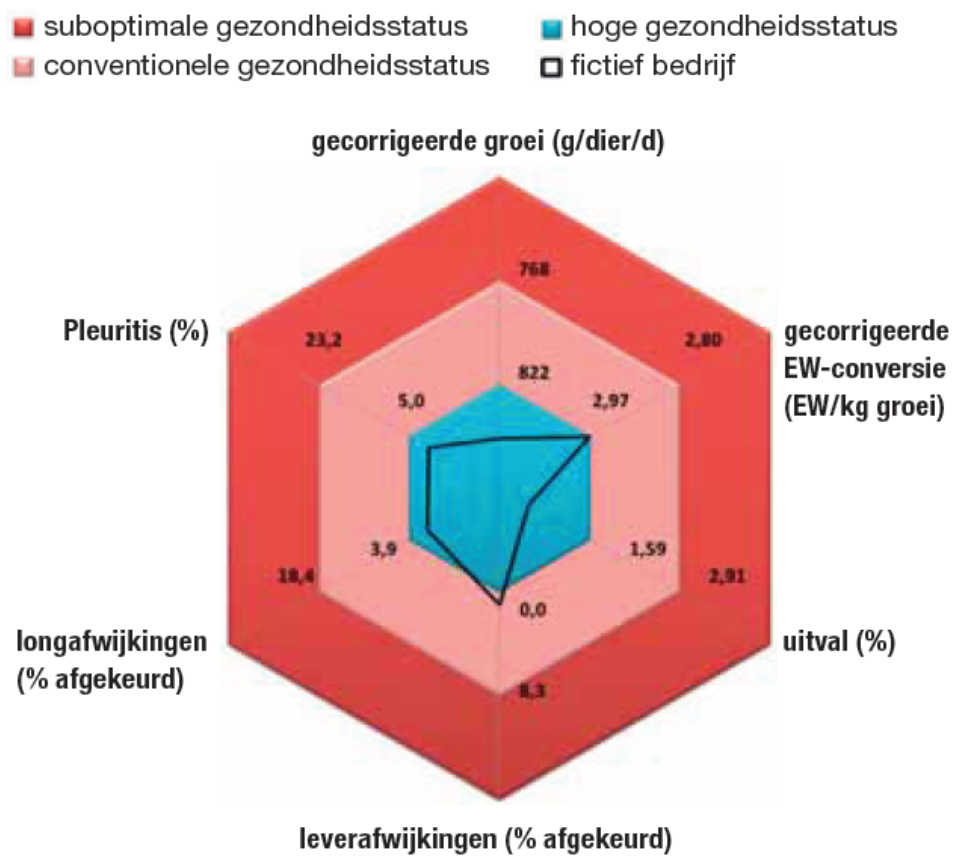

Figuur 1 Voorbeeld van de weergave van de gezondheidsstatus van een vleesvarkensbedrijf in het spinnenweb concept (Kampman-van de Hoek, 2015). 
Binnen het project werd ook gekeken naar de consistentie van de score van bedrijven over jaren binnen het spinnenweb. Daarvoor werden gegevens van twee opeenvolgende jaren gebruikt en onderling vergeleken. Hieruit bleek dat het concept goede consistentie in score liet zien bij vergelijking van de scores over de jaren 2011 en 2012.

De basis van het beschreven concept voor vleesvarkensbedrijven zou ook kunnen worden gebruikt voor het ontwikkelen van een dergelijk concept voor vleeskuikenbedrijven. Een beperking in de vleeskuikensector is dat slachtgegevens (met uitzondering van \% afkeuring en voetzoollaesie score) niet routinematig per koppel worden gemonitord. Het \% afkeuring en voetzoollaesie score zijn beide kenmerken die onder invloed staan van verschillende factoren en niet een op een aan gezondheid te koppelen zijn. Deze gegevens kunnen extra informatie verschaffen over de gezondheidsstatus van de kuikens op een bedrijf. Mogelijk relevante parameters voor het bepalen van de gezondheidsstatus bij vleeskuikenbedrijven zijn:

- Groei/dier/dag

- Voederconversie

- Uitval (totaal en in $1^{\mathrm{e}}$ week)

- Voetzoollaesie score

- Uniformiteit bij afleveren

- Mestconsistentie

- Gezondheidskosten

- Mate van (algemene of specifieke) activatie van het immuunsysteem

\section{Doel project}

Het ontwikkelen van een concept voor de bepaling van de gezondheidsstatus van vleeskuikenbedrijven is een onderdeel van een groter project: "Customised nutrition of broilers". Dit project heeft als doel om stikstofverliezen bij pluimvee te verminderen door kennis te ontwikkelen om voeders voor vleeskuikens ten aanzien van hun aminozuursamenstelling af te kunnen stemmen op de gezondheidsstatus van de dieren. Door toepassing van deze kennis wordt het immuunsysteem van het dier voor wat betreft de aminozuurvoorziening optimaal ondersteund en worden de productieprestaties onder praktijkomstandigheden geoptimaliseerd, leidend tot een verbetering van de stikstofbenutting uit het voer en een vermindering van de stikstofverliezen in het milieu.

Het doel van het onderhavige onderzoek was om meer inzicht te krijgen in welke gegevens in de praktijk bij vleeskuikenbedrijven gemonitord worden. Dit met als doel om te onderzoeken welke routinematig verzamelde gegevens, direct of indirect gerelateerd aan diergezondheid, het meest relevant zijn om te gebruiken voor de bepaling van de gezondheidsstatus van vleeskuikenbedrijven. Het uiteindelijk doel van dit onderzoek was om na te gaan of er een voldoende groot bedrijfseffect bestaat ten aanzien van vleeskuikengezondheid om op termijn voeders te formuleren afgestemd op de gezondheidsstatus van vleeskuikenbedrijven.

In hoofdstuk 2 worden de gebruikte materialen en methoden besproken en in hoofdstuk 3 de resultaten en discussie omtrent de resultaten zijn weergegeven. 


\section{Materiaal en methoden}

Om meer inzicht te genereren omtrent de gegevens die door verschillende voerfabrikanten worden bijgehouden is aan de verschillende bedrijven gevraagd om een geanonimiseerde database met gegevens van minimaal de laatste 2 jaar te overhandigen aan WLR. Drie voerfabrikanten hebben hier gehoor aan gegeven en de gegevens van die databases zijn gebruikt voor analyse.

Doordat de databases verschilden qua layout zijn ze eerst in een geüniformeerde database samengebracht. Na samenvoeging van de drie verschillende databases bevatte de database in totaal gegevens van 1.730 koppels. De database is gecontroleerd op afwijkende waarden en sterk afwijkende data is verwijderd. Daarnaast zijn individuele vleeskuikenbedrijven met minder dan vijf koppels, koppels met ontbrekende voetzoollaesie score gegevens en langzaam groeiende rassen uit de database verwijderd. Na deze exercitie bleven er 80 verschillende vleeskuikenbedrijven over met in totaal 1.054 koppels (gemiddeld 13 koppels per bedrijf). Dit betekent dat de opgeschoonde database ongeveer $10 \%$ van alle koppels in Nederland per jaar bevatte. De gegevens in de uiteindelijke database zijn afkomstig van de periode tussen half 2013 en half 2016 (circa 3 jaar).

\section{Methodiek/analyse}

Voor de kenmerken groei, groei-index (leeftijd gecorrigeerde groei), eindgewicht, voederconversie, uitval en voetzoollaesie score zijn de systematische bedrijfseffecten van vleeskuikenbedrijven geschat. Hierbij is gecorrigeerd voor seizoen en tijdstrend in de data, aangezien vleeskuikenkoppels in verschillende seizoenen zijn opgestart en het feit dat kenmerken gemiddeld op alle bedrijven in de loop van de tijd veranderen van niveau (door fokkerij- en marktinvloeden).

Voor het schatten van de fixed effecten van seizoen (via fourier-transformatie van kalenderdag zoals in Yassin et al., 2008), leeftijd moederdieren (met behulp van woodcurve, zie Yassin et al., 2008) en tijdstrend (met $3^{\mathrm{e}}$ graads polynoom), en daarnaast het simultaan schatten van zowel de tussenbedrijfseffecten (constante verschillen tussen vleeskuikenbedrijven) als de binnen-bedrijfseffecten (de variatie binnen een vleeskuikenbedrijf, dus tussen koppels in de tijd op hetzelfde bedrijf), is gebruikt gemaakt van een gemengd (mixed) regressiemodel.

Voor de kenmerken 'voetzoollaesie score' en 'uitval' is een logtransformatie $\ln \{y\}$ toegepast. De fixed effecten zijn primair als correctiefactoren bedoeld, en zijn in geval van niet-significantie niet verwijderd uit het uiteindelijk gebruikte (eind)model voor de analyse van de data.

Het maximale model is als volgt:

$\underline{Y}_{i j k}=\beta_{0 k}+\beta_{1.1} * t+\beta_{1.2} * t^{2}+\beta_{1.3} * t^{3}+\beta_{2} * X_{1}+\beta_{3} * X_{2}+\underline{\varepsilon}_{i}+\underline{\varepsilon}_{i j k}$

Met:

$\beta_{0 k} \quad:$ Geschatte niveau voor koppels van bedrijf $\mathrm{i}$, in koppel $\mathrm{j}$, gevoerd met voer van leverancier $\mathrm{k}$

$\beta_{1.1}, \beta_{1.2}, \beta_{1.3}$ : Geschatte parameters $3^{\mathrm{e}}$-graads polynoom; tijdstrend in de periode.

$t \quad:$ Tijd in dagen (vanaf $1^{\mathrm{e}}$ datum geboortedatum in dataset); $\mathrm{t}$ is maximaal 1087.

$\beta_{2}, \beta_{3} \quad$ : Parameters voor seizoenseffect (na fourier transformatie van kalenderdagnummer)

$X_{1}, X_{2} \quad: \operatorname{Sinus}\left(\frac{2 \pi}{365} * d\right), \operatorname{cosinus}\left(\frac{2 \pi}{365} * d\right)$, met $d$ als dagnummer in het jaar (op basis van geboortedatum vleeskuikens, dus van 1 tot 365).

$\underline{\varepsilon}_{i}, \underline{\varepsilon}_{i j} \quad$ : Random effect van vleeskuikenbedrijf $i$, resp. koppel $j$ (binnen $i$ ). 


\section{$3 \quad$ Resultaten en discussie}

\subsection{Beschrijving van de data}

\subsubsection{Frequentie van algemene gegevens en kengetallen}

In Tabel 1 zijn de verschillende algemene gegevens en kengetallen en de frequentie van voorkomen in de verschillende databases weergegeven. Uit de tabel blijkt dat de databases niet homogeen waren en bepaalde algemene gegevens en kengetallen niet bij alle fabrikanten worden bijgehouden. Overall kan geconcludeerd worden dat de belangrijkste kengetallen (uitval \%, groei/dier/dag, VC $_{1500}$ en voetzoollaesie score) bij alle voerfabrikanten worden bijgehouden.

Tabel 1 Frequentie van algemene gegevens en kengetallen die in de verschillende database worden bijgehouden.

\begin{tabular}{|c|c|c|c|}
\hline Algemene gegevens & Frequentie & Kengetallen & Frequentie \\
\hline Klant & $3 x$ & Uitval (\%) & $3 x$ \\
\hline Opzet datum & $2 x$ & Aflevergewicht (g) & $3 x$ \\
\hline Slacht datum & $3 x$ & Groei/dier/dag (g) & $3 x$ \\
\hline Aantal dagen & $1 x$ & VC netto $(\mathrm{kg} / \mathrm{kg})$ & $3 x$ \\
\hline Opzet aantal & $3 x$ & $\mathrm{VC}_{1500}(\mathrm{~kg} / \mathrm{kg})$ & $3 x$ \\
\hline Slacht aantal & $1 x$ & $\mathrm{VC}_{2500}(\mathrm{~kg} / \mathrm{kg})$ & $1 x$ \\
\hline \# kuikens / $\mathrm{m}^{2}$ & $2 x$ & Afkeur (\%) & 21 \\
\hline Tarwe bijmengen (\%) & $1 x$ & & \\
\hline
\end{tabular}

\subsubsection{Gemiddelde en spreiding kengetallen}

In Tabel 2 zijn de gemiddelde weergegeven van de 4 belangrijkste kengetallen (uitval, groei/dier/dag, $\mathrm{VC}_{1500}$ en voetzoollaesie score). Uit de tabel blijkt dat de verschillende kengetallen goed overeen komen met de waarden die KWIN (2016-2017) verstrekt. Voor uitval\%, groei/dier/dag en VC 1500 geeft KWIN, respectievelijk de waarden $3,5,58,0$ en 1,318 . Verder valt op dat de spreiding (SD) van uitval en voetzoollaesie score hoog is en van groei/dier/dag, VC netto en VC $_{1500}$ relatief laag. Dit blijkt ook uit de variatiecoëfficiënt ( $C V \%$ ) die ook in de tabel is weergegeven. Deze is voor uitval en voetzoollaesie score respectievelijk 36,7 en $56,7 \%$ terwijl die voor groei/dier/dag en $\mathrm{VC}_{1500} 3,8$ en $4,4 \%$ is.

Tabel 2 Gemiddelde van de kengetallen en de gemiddelde warde over alle bedrijven van de SD, minimum en maximum.

\begin{tabular}{lcc} 
& Gemiddeld $(\text { gem min-max })^{1}$ & Gemiddeld SD ${ }^{2}\left(\mathrm{CV} \%^{3}\right)$ \\
Uitval $(\%)$ & $3,6(1,9-6,3)$ & $1,32(36,7)$ \\
\hline Groei/dier/dag $(\mathrm{g})$ & $59,4(55,6-63,3)$ & $2,28(3,8)$ \\
\hline $\mathrm{VC}_{1500}(\mathrm{~g} / \mathrm{g})$ & $1,281(1,196-1,391)$ & $0,056(4,4)$ \\
\hline Voetzoollaesie score $(0-200)$ & $59,4(16,7-123,0)$ & $33,7(56,7)$ \\
\hline${ }^{1}$ Gemiddelde min en max is de gemiddelde min en max van alle bedrijven. \\
${ }^{2}$ Gemiddelde SD is gemiddelde SD over koppels binnen bedrijven. \\
${ }^{3} \mathrm{CV} \%=$ variatie coëfficiënt (SD / gemiddelde waarde).
\end{tabular}

De grote spreiding voor voetzoollaesie score van alle opeenvolgende koppels vleeskuikens van 2 voorbeeld bedrijven is duidelijk weergegeven in Figuur 2. Voorbeeldbedrijf $A$ en $B$ hadden gemiddeld een score van respectievelijk 27 en 54. Bedrijf B had tijdens de eerste vier koppels een voetzoollaesie score van gemiddeld 50 terwijl die bij de volgende 2 koppels gemiddeld rond de 100 lag. Twee koppels later is de voetzoollaesie weer lager dan 10 terwijl enkele koppels later een uitschieter van meer dan 
130 werd genoteerd. Ook bij bedrijf A met een gemiddeld lagere voetzoollaesie score zagen we een grote spreiding tussen enkele koppels lager dan 10 met een tweetal uitschieters naar boven de 60 .

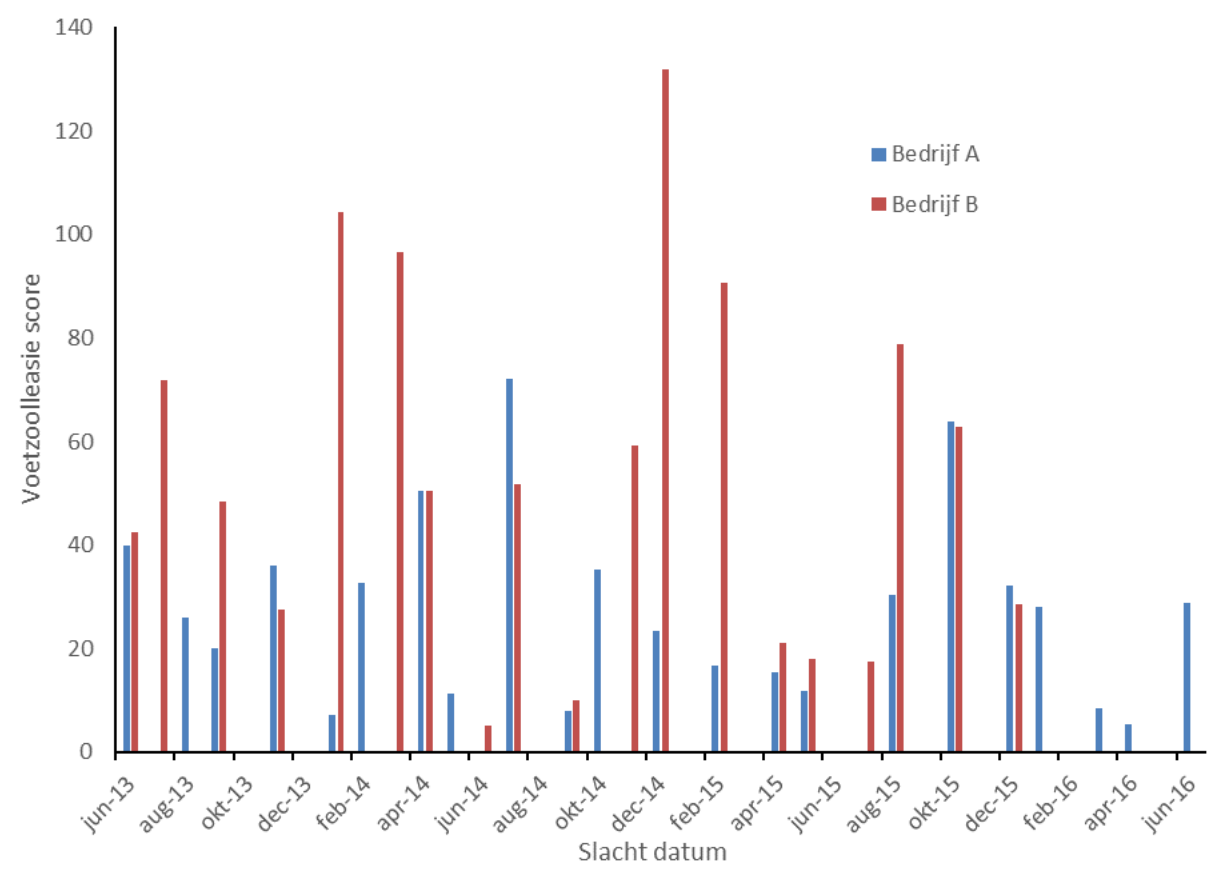

Figuur 2 Voetzoollaesie score van opeenvolgende koppels kuikens van twee verschillende bedrijven in de tijd.

De uitval en voetzoollaesie score resultaten van de verschillende bedrijven zijn verdeeld in 4 klassen van elk $25 \%$ en weergegeven in Tabel 3 en 4 . Uit de tabellen blijkt in het algemeen dat met toenemende uitval en voetzoollaesie score ook de spreiding (SD) toeneemt.

Tabel 3 Gemiddelde, SD, minimum en maximum van uitval\% naar klasse.

\begin{tabular}{lcccc} 
Klasse & Gemiddeld & SD & Min & Max \\
$0-25 \%$ & 2,65 & 1,07 & 1,31 & 4,92 \\
\hline $25-50 \%$ & 3,39 & 1,21 & 1,64 & 6,03 \\
\hline $50-75 \%$ & 3,92 & 1,56 & 1,75 & 6,83 \\
\hline $75-100 \%$ & 4,58 & 1,42 & 2,82 & \\
\hline
\end{tabular}

${ }_{1}^{1}$ Gemiddelde min en max is de gemiddelde min en max van alle bedrijven.

2 Gemiddelde SD is gemiddelde SD van alle bedrijven.

Tabel 4 Gemiddelde, SD, minimum en maximum van voetzoollaesie score naar klasse.

\begin{tabular}{lcccc} 
Klasse & Gemiddeld & SD & Min & Max \\
$0-25 \%$ & 29,9 & 23,0 & 4,6 & 75,2 \\
\hline $25-50 \%$ & 50,0 & 32,4 & 9,9 & 117,7 \\
\hline $50-75 \%$ & 66,9 & 36,9 & 20,5 & 138,0 \\
\hline $75-100 \%$ & 90,8 & 42,4 & 31,9 & 161,2 \\
\hline
\end{tabular}

${ }^{1}$ Gemiddelde min en max is de gemiddelde min en max van alle bedrijven.

2 Gemiddelde SD is gemiddelde SD van alle bedrijven.

\subsubsection{Seizoen effect}

Het effect van het seizoen op de resultaten van de verzamelde data is onderzocht. Voor alle kengetallen bleek er een effect van seizoen. De resultaten hiervan zijn weergegeven in Figuur 3 . Uit de figuur blijkt dat met name de voetzoollaesie score sterk beïnvloed wordt door het seizoen en in mindere mate groei/dier/dag, uitval\% en $\mathrm{VC}_{1500}$. Voor de voetzoollaesie score blijkt dat vooral in de zomermaanden (warmer en mogelijk droger) de gemiddelde voetzoollaesie score het laagst was. 

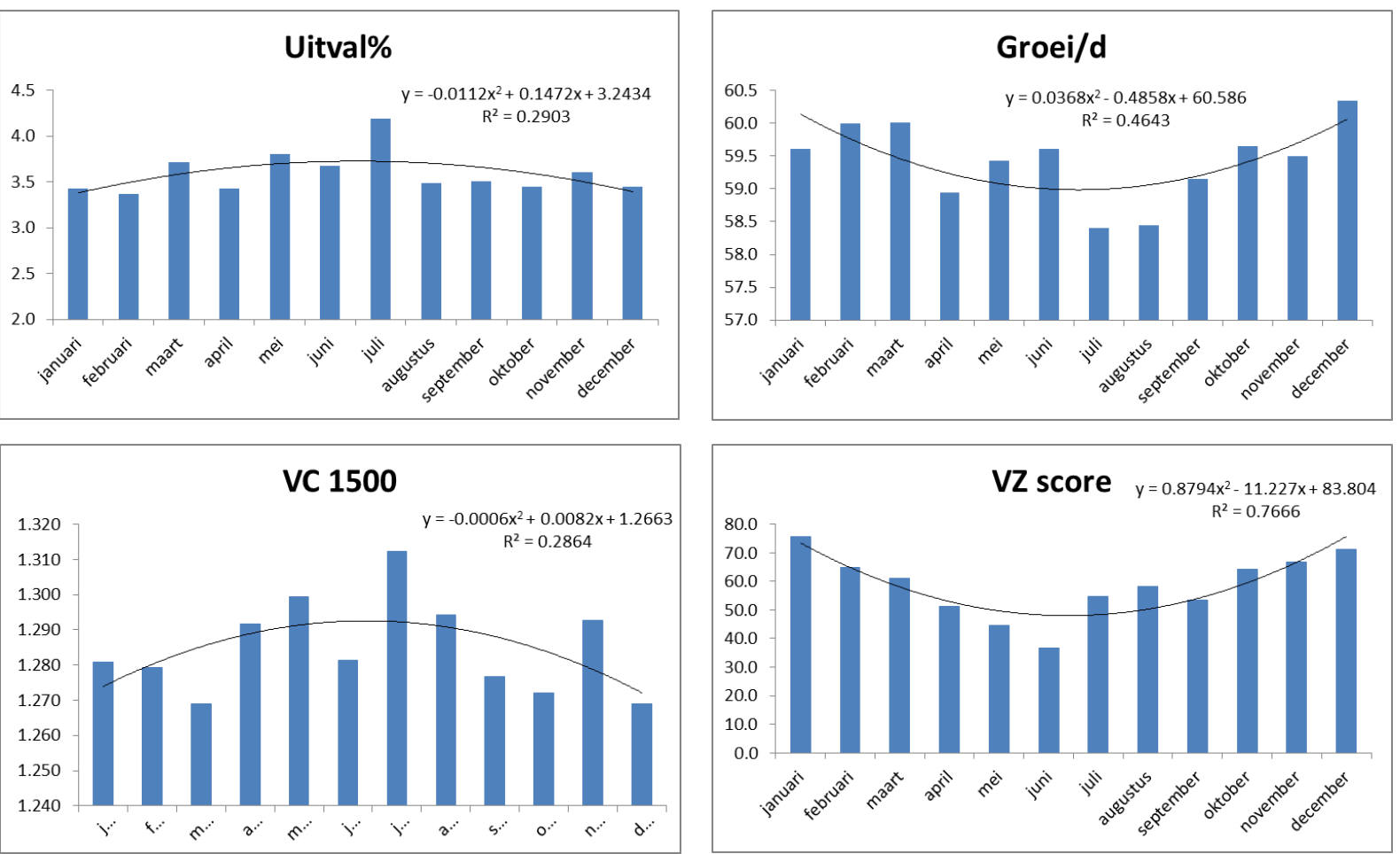

Figuur 3 Effect van seizoen op de verschillende kengetallen.

\subsection{Statistische analyse}

In Tabel 5 en 6 staan de relatieve groottes van variantiecomponenten bedrijf (tussenvleesk.bedrijfsvariatie) en koppel (binnen-vleesk.bedrijfsvariatie) voor de verschillende kenmerken. Belangrijk is te constateren dat het opnemen van de variantiecomponent vleesk.bedrijf in alle gevallen een groter deel van de bestaande variatie in waarden van deze kenmerken werd verklaard. Dit gold voor alle kenmerken en in zowel de situatie met correctie als in de situatie zonder correctie voor het effect van trend, seizoen en voerleverancier. Dit betekent dat voor alle kenmerken geldt dat er een invloed van het vleeskuikenbedrijf op de prestatie van een koppel vleeskuikens is. Sommige vleeskuikenbedrijven presteren doorgaans beter dan een gemiddeld bedrijf, en andere bedrijfven presteren doorgaans minder dan een gemiddeld bedrijf. Deze variatie van niveau van de bedrijven is met deze analyses geschat. Verder lijkt de relatieve invloed van vleeskuikenbedrijf het grootst voor de 'pure' productiekenmerken (groei/dier/dag en $\mathrm{VC}_{1500}$ ) en iets minder voor gezondheidskenmerken (uitval en voetzoollaesie score).

In het geval van ongecorrigeerd voor het effect van trend, seizoen en voerleverancier (Tabel 5 ) is de relatieve grootte van variantie van de bedrijfseffecten voor de kenmerken groei-index

(leeftijdgecorrigeerde groei), voederconversie, eindgewicht en productietal zelfs groter dan $50 \%$. Dit betekent dat de verschillen tussen de vleeskuikenbedrijven zelfs groter zijn dan de verschillen binnen vleeskuikenbedrijven (dus de verschillen tussen koppels in de tijd van hetzelfde bedrijf). Na correctie zijn de bedrijfseffecten voor de meeste kenmerken iets gedaald (Tabel 6). Dit heeft waarschijnlijk te maken met het feit dat de vleeskuikenkoppels van één databron gemiddeld op een lager lichaamsgewicht werden geslacht. 

correctiefactoren trend, seizoen en databron).

\begin{tabular}{llr} 
& Bedrifis-effect $\left(\varepsilon_{i}\right)$ & Koppel-efiect $\left(\varepsilon_{i j}\right)$ \\
Groei/dier/dag & $47 \%$ & $53 \%$ \\
\hline Groei-index & $58 \%$ & $42 \%$ \\
\hline Eindgewicht & $53 \%$ & $47 \%$ \\
\hline VC & $55 \%$ & $45 \%$ \\
\hline VC 1500 & $45 \%$ & $55 \%$ \\
\hline Uitval $(\%)$ & $20 \%$ & $80 \%$ \\
\hline Voetzoollaesie score & $30 \%$ & $70 \%$ \\
\hline PG & $58 \%$ & $42 \%$ \\
\hline
\end{tabular}

Tabel 6 Schattingen voor relatieve grootte van de variantiecomponenten (met correctiefactoren trend, seizoen en databron).

\begin{tabular}{|c|c|c|}
\hline & Bedrijfs-effect $\left(\varepsilon_{i}\right)$ & Koppel-effect $\left(\underline{\varepsilon}_{\mathrm{ij}}\right)$ \\
\hline Groei/dier/dag & $44 \%$ & $56 \%$ \\
\hline Groei-index & $56 \%$ & $44 \%$ \\
\hline VC & $48 \%$ & $52 \%$ \\
\hline $\mathrm{VC}_{1500}$ & $38 \%$ & $62 \%$ \\
\hline Uitval (\%) & $18 \%$ & $82 \%$ \\
\hline PG & $46 \%$ & $54 \%$ \\
\hline
\end{tabular}

In tabel 7 is het totale beeld gegeven van bijdrage van de geevalueerde bronnen van variatie in deze dataset. Belangrijk om hierbij te vermelden is dat data van drie verschillende herkomsten zijn gebruikt. De betekenis van het effect van databron in de huidige analyse is hierdoor beperkt.

In principe is er een grote overeenkomst tussen tabel 5 en 7. Met de correctie voor databron worden doorgaans de bedrijfseffecten verklaard, aangezien de meeste bedrijven in de hele periode vertegenwoordigd waren in dezelfde databron. Met de correctiefactor seizoen en trend wordt de binnen-bedrijfsvariatie (koppelvariatie binnen een vleeskuikenbedrijf in de tijd) verklaard.

Tabel 7 Schattingen voor relatieve grootte van de variantiecomponenten (met berekende grootte van variantiecomponenten voor trend, seizoen en databron) op waarden voor verschillende koppel kenmerken, direct of indirect gerelateerd aan gezondheid.

\begin{tabular}{|c|c|c|c|c|c|}
\hline & $\begin{array}{c}\text { Bedrijfs-effect } \\
\left(\underline{\varepsilon}_{i}\right)\end{array}$ & $\begin{array}{c}\text { Koppel-effect } \\
\left(\underline{\varepsilon}_{\mathrm{ij}}\right)\end{array}$ & Trend & Seizoen & Databron \\
\hline Groei/dag & $38 \%$ & $48 \%$ & $6 \%$ & $1 \%$ & $7 \%$ \\
\hline Eindgewicht & $38 \%$ & $43 \%$ & $5 \%$ & $1 \%$ & $13 \%$ \\
\hline VC & $41 \%$ & $44 \%$ & $0 \%$ & $0 \%$ & $15 \%$ \\
\hline $\mathrm{VC}_{1500}$ & $32 \%$ & $53 \%$ & $0 \%$ & $1 \%$ & $14 \%$ \\
\hline Voetzoollaesie score & $26 \%$ & $63 \%$ & $0 \%$ & $5 \%$ & $6 \%$ \\
\hline PG & $35 \%$ & $41 \%$ & $0 \%$ & $1 \%$ & $23 \%$ \\
\hline
\end{tabular}

In tabel 8 is een weergave van de significantie van de correctiefactoren per kenmerk weergegeven terwijl in Tabel 9 de bijbehorende waardes zijn weergegeven. Voor de meeste kenmerken (behalve voor productiegetal en $\mathrm{VC}_{1500}$ ) bleek een significant effect van trend in de periode waarover gegevens in de dataset zijn verzameld. In vrijwel de meeste gevallen (alleen niet voor VC) bleek er sprake van een significant seizoenseffect voor het betreffende kenmerk. Dit seizoenseffect bleek vooral een zomer/winter effect. In de meeste gevallen (alleen niet voor het kenmerk uitval) bleek er een significant effect van databron. 
Schattingen voor effecten van trend, seizoen en databron op waarden voor verschillende koppel kenmerken, direct of indirect gerelateerd aan gezondheid.

\begin{tabular}{|c|c|c|c|c|c|c|c|}
\hline & $\begin{array}{l}\text { Tijdstrend } \\
\text { Iineair } \\
\left(B_{1.1}\right)\end{array}$ & $\begin{array}{c}\text { Tijdstrend } \\
\text { (kwadr.) } \\
B_{1.2}\end{array}$ & $\begin{array}{l}\text { Tijdstrend } \\
\text { (tert.) } B_{1,3}\end{array}$ & $\begin{array}{l}\text { Seizoen } \\
\text { (sinus) } B_{2}\end{array}$ & $\begin{array}{c}\text { Seizoen } \\
\text { (cosinus) } \\
B_{3}\end{array}$ & $\begin{array}{c}\text { Databron } 2 \\
\text { t.o.v. } 1\end{array}$ & $\begin{array}{c}\text { Databron } 3 \\
\text { t.o.v. } 1\end{array}$ \\
\hline Groei-index & - & + & - & NS & + & - & NS \\
\hline Eindgewicht & - & + & - & NS & + & - & NS \\
\hline Uitval (\%) & + & - & + & NS & - & NS & NS \\
\hline Voetzoollaesie score & - & NS & NS & - & + & NS & - \\
\hline PG & NS & NS & NS & NS & + & NS & + \\
\hline
\end{tabular}

Tabel 9 Waarde schattingen voor effecten van trend, seizoen en databron op waarden voor verschillende koppel kenmerken, direct of indirect gerelateerd aan gezondheid.

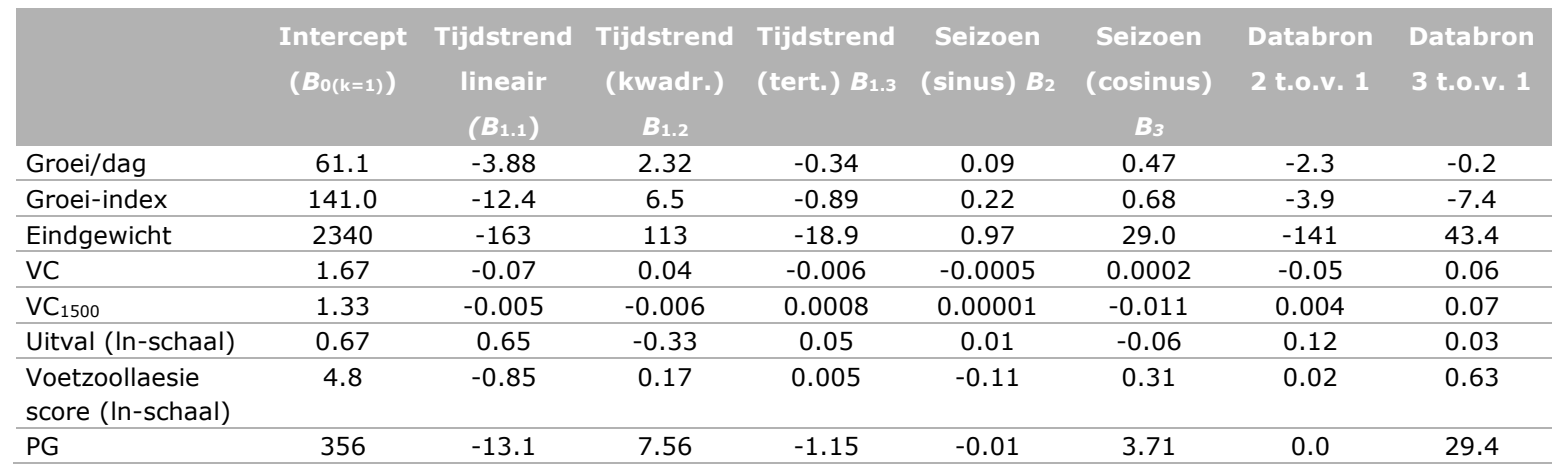

\section{Conclusie statistische analyse}

Zowel bij gebruik van een model zonder als met correctiefactoren (Tabel 5 en 6 ) is de verklaring door de bedrijfseffecten van de productieresultaten groei/dag en $V_{1500}$ vrij groot. Voor groei/dag is de verklaring van het bedrijfseffect respectievelijk 47 (zonder correctie ) en 44\% (met correctie), terwijl die voor $\mathrm{VC}_{1500}$ respectievelijk 45 en $38 \%$ is van de totale variatie. Voor uitval en voetzoollaesie score (na log-transformatie) is de verklaring door de bedrijfseffecten kleiner met waarden, voor respectievelijk zonder en met correctiefactoren in het model, van 20 en $18 \%$ voor uitval en 30 en $29 \%$ voor voetzoollaesie score. 


\section{$4 \quad$ Conclusie}

Uit de analyse van gegevens wordt geconcludeerd dat:

- Voor de kenmerken uitval, groei per dag, de gecorrigeerde voederconversie $\left(\mathrm{VC}_{1500}\right)$, en voetzoollaesie score er een significante invloed bestaat van de factor bedrijf.

- $\quad$ Het bedrijfseffect op de kenmerken groei/dag en $V_{1500}$ groter is dan op de kenmerken uitval en voetzoollaesie score.

- De variatie in gezondheidsstatus tussen vleeskuikenbedrijven, ten opzichte van de variatie tussen individuele koppels binnen bedrijven, voldoende groot is om in de toekomst de voersamenstelling op bedrijfsniveau af te stemmen op de gezondheidsstatus van vleeskuikens. 


\section{Literatuur}

Kampman - van de Hoek, E. 2015. Impact of health status on amino acid requirements of growing pigs. Towards feeding strategies for farms differing in health status. PhD thesis, Wageningen University, Wageningen, NL.

Klasing, K.C. 1998. Nutritional modulation of resistance to infectious diseases. Poultry Science 77:1119-1125.

Klasing, K.C., 2007. Nutrition and the immune system, British Poultry Science, 48:5, 525-537, DOI: $10.1080 / 00071660701671336$.

Korver, D.R. and K.C. Klasing. 2001. Influence of nutrition on immune status of the bird. Proceedings of the 24th Technical Turkey Conference. p43.

Van der Peet-Schwering, C.M.C. en A.J.M. Jansman. 2007. Nutriëntbehoefte van varkens onder suboptimale omstandigheden. NL Rapport no. 68. Lelystad, The Netherlands: WUR Livestock Research.

Yassin, H., A.G.J. Velthuis, M. Boerjan, J.W. van Riel, and R.B.M. Huirne. 2008. Field study on broiler eggs hatchability. Poult. Sci. 87:2408-2417. 

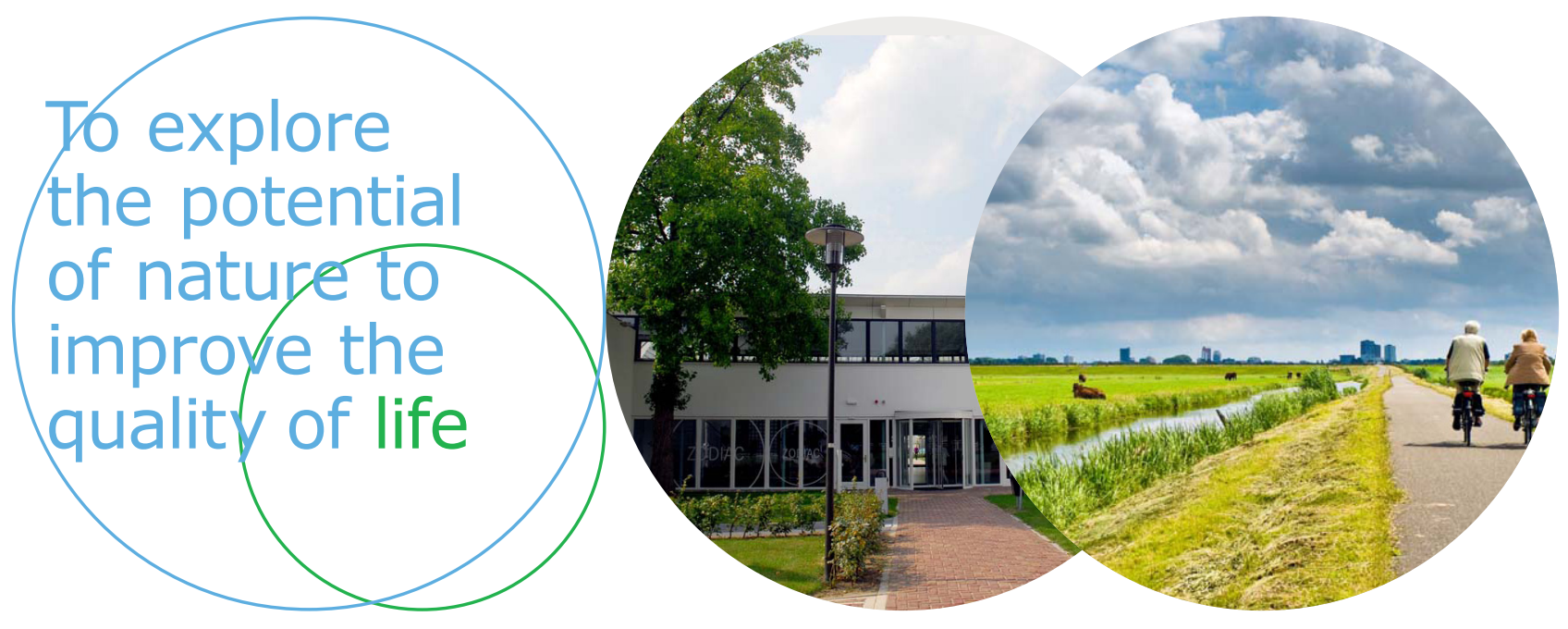

Wageningen Livestock Research Postbus 338

Wageningen Livestock Research ontwikkelt kennis voor een zorgvuldige en $6700 \mathrm{AH}$ Wageningen

T 0317483953

renderende veehouderij, vertaalt deze naar praktijkgerichte oplossingen en innovaties, en zorgt voor doorstroming van deze kennis. Onze wetenschappelijke E info.livestockresearch@wur.nl www.wur.nl/ livestock-research kennis op het gebied van veehouderijsystemen en van voeding, genetica, welzijn en milieu-impact van landbouwhuisdieren integreren we, samen met onze klanten, tot veehouderijconcepten voor de $21 \mathrm{e}$ eeuw.

De missie van Wageningen University \& Research is 'To explore the potential of nature to improve the quality of life'. Binnen Wageningen University \& Research bundelen 9 gespecialiseerde onderzoeksinstituten van Stichting Wageningen Research en Wageningen University hun krachten om bij te dragen aan de oplossing van belangrijke vragen in het domein van gezonde voeding en leefomgeving. Met ongeveer 30 vestigingen, 6.500 medewerkers en 10.000 studenten behoort Wageningen University \& Research wereldwijd tot de aansprekende kennisinstellingen binnen haar domein. De integrale benadering van de vraagstukken en de samenwerking tussen verschillende disciplines vormen het hart van de unieke Wageningen aanpak. 